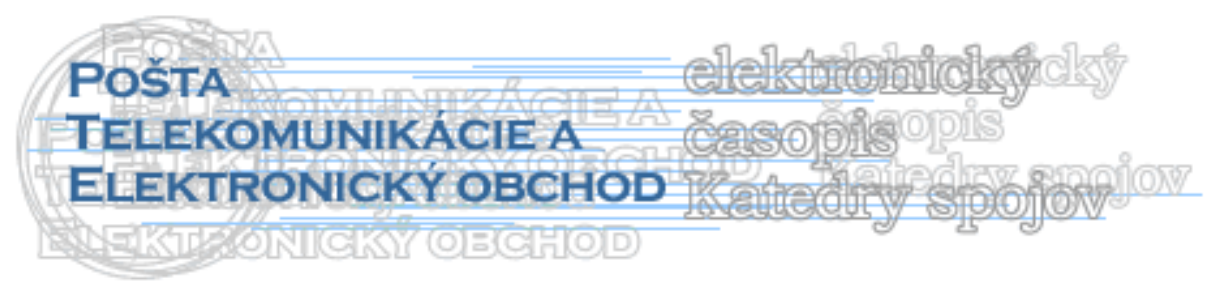

\title{
UŽÍVATELSKÉ TESTOVANIE WEBOVEJ STRÁNKY S VYUŽITÍM OČNEJ KAMERY
}

\author{
Lucia Dobáková, Alena Chrenková*
}

\begin{abstract}
The article is focused on user testing of website through eye-tracking. First, there is characterized user testing and its steps, and then eye-tracking is described as a tool for testing the website of selected e-commerce on target group. In conclusion, there are results of testing and suggestions for improving the website.
\end{abstract}

Keywords: eye-tracking, user testing, user friendly website, target group

\section{Úvod}

V súčasnosti je nakupovanie prostredníctvom elektronických obchodov vel'mi rozšírené a aj d'alej si získava čoraz viac priaznivcov. Nestačí len ponúkat' lákavé produkty za priaznivé ceny, prostredie internetu si vyžaduje ovel’a viac. Kl'účovým nástrojom elektronického obchodu je kvalitná webová stránka, na ktorej sa návštevník rýchlo a jednoducho zorientuje a nájde všetky potrebné informácie pre svoje nákupné rozhodovanie.

\section{Užívatel'ské testovanie}

Elektronický obchod by si mal otestovat' webovú stránku, prostredníctvom ktorej realizuje predaj, či už pred jej samotným spustením, ale aj priebežne počas existencie. Potrebuje vediet', ako stránku - jej prehl'adnost', jednoduchost' a intuitívnu prácu s ňou vnímajú jej skutoční užívatelia.

Ako zistit', že sa návštevníkom webová stránka l'ahko používa? Mnohí podnikatelia často zastávajú názor, že s ich webom nikto nemá problém a ak áno, chyba je v ňom, lebo je internetovým začiatočníkom. Neuvedomujú si fakt, že návštevníci, ktorí sa na ich stránke nevyznajú a zdá sa im neprehl'adná, odchádzajú a nemusia sa už viac vrátit'. Každý deň takto strácajú užívatel'ov, ktorí mohli byt' ich potenciálnymi zákazníkmi a zároveň zdrojom ich príjmov. Odpoved’ou na otázku, položenú na začiatku, je realizácia testovania webu na užívatel'och. Testovanie pomáha odhalit' najvýraznejšie problémy, ktorým musia návštevníci webovej stránky čelit'. [7]

Štruktúra stránky má byt' pre užívatel'ov prehl'adná, jednoduchá a atraktívna; obsah aktuálny a dôveryhodný. Ak tieto základné vlastnosti nesplńna, vzbudzuje u potenciálnych zákazníkov nedôveru a tí ju viac nemusia nenavštívit'. [3]

\footnotetext{
* Ing. Lucia Dobáková, e-mail: lucia.dobakova@gmail.com Ing. Alena Chrenková, PhD., Kompava, spol. s r. o., Piešt’anská 44, 91501 Nové Mesto nad Váhom, tel: +421903718 044, e-mail: marketing@kompava.sk
} 


\section{Typy uživatel'ského testovania}

V súčasnosti existuje niekol'ko spôsobov ako stránku otestovat'. Je možné si vybrat' zo širokej ponuky typov užívatel'ského testovania, pričom pri výbere konkrétneho typu treba brat' ohl'ad na ciele testovania, konkrétne účely a požiadavky.

Medzi najpoužívanejšie typy užívatel'ského testovania patria nasledovné:

- klasické užívatel'ské testovanie,

- vzdialené testovanie,

- testovanie technického riešenia,

- testovanie očnou kamerou,

- testy navigácie,

- kvantitatívne testovanie. [9]

\section{Testovanie očnou kamerou}

Pre realizáciu výskumu sme využili testovanie očnou kamerou, pomocou ktorého je možné vidiet' webovú stránku očami užívatel'ov. Očná kamera je zariadenie, ktoré umožňuje zaznamenávat' pohyb zreničky l'udského oka a tým určit', kam sa užívatel' pozerá. Už v 50. rokoch minulého storočia sa prvýkrát vyskytlo monitorovanie pohybu zraku. V začiatkoch sa používali mechanické metódy, ktoré využívali zrkadlo, fotografický materiál či infračervené svetlo.

Neskôr sa do popredia dostali metódy, ktoré aplikovali video a tiež elektrostatické metódy. Doteraz spomenuté metódy však neboli pre testerov (reprezentatívnu skupinu užívatel'ov) vel'mi príjemné a komfortné. Taktiež metóda založená na zaznamenávaní prostredníctvom videa bola značne obmedzená, lebo neumožňovala pohyb hlavy pri testovaní. [2]

S rozvojom technológií vo všetkých oblastiach nastal posun aj v monitorovaní pohybu zraku. Hlavným zámerom bolo vytvorit' také podmienky, aby účastníci testovania mohli nerušene realizovat' stanovené úlohy. Odstránili sa mechanické zariadenia (prilba s kamerou, fixácia hlavy a pod.) a tým sa vytvorili ideálne podmienky pre testovanie. [1]

Pri samotnom testovaní pomocou očnej kamery riešia testeri reálne úlohy podl'a stanoveného scenára. Výsledkom je identifikácia problémových oblastí a objavenie potenciálu rozvoja webovej stránky. Pri testovaní očnou kamerou sa treba zamerat' na konkrétnu ciel'ovú skupinu a tak pochopit’ jej správanie. [10]

V porovnaní s inými metódami testovania je zaznamenávanie reakcií oka, ktoré užívatel' nevníma, hlavnou výhodou daného testovania. Užívatelia často nevedia presne popísat', čo si všimli ako prvé a tiež čo tomu predchádzalo. Testovanie očnou kamerou je v tomto prípade ideálnou vol'bou. [5]

\section{Priebeh uživatel'ského testovania pomocou očnej kamery}

Pri užívatel'skom testovaní je potrebné si zaobstarat' reprezentatívnu skupinu užívatel'ov, ktorí budú následne pozorovaní, ako používajú webovú stránku. Samotný priebeh testovania je nasledovný:

- Je potrebné vel'mi dobre poznat' pozorovanú webovú stránku, jej ciele a funkcie.

- Následne je treba pripravit' scenár testovania s úlohami pre testerov, ktoré ich budú podnecovat' $\mathrm{k}$ bežnému správaniu sa na stránke.

- Ďalším krokom je zaistenie reprezentatívnej vzorky užívatel'ov (testerov), ktorí najlepšie zodpovedajú návštevníkom testovanej stránky.

- Uskutočnenie samotného užívatel'ského testovania, kde každý tester plní stanovené úlohy. Moderátor testovania sleduje ich činnost', prípadne im kladie otázky. 
- Posledným krokom testovania je zhrnutie jeho priebehu a výsledkov do záverečnej správy. Okrem toho sú v nej obsiahnuté odporúčania, zistené chyby a návrhy, ako dané nedostatky najlepšie eliminovat'. [8]

\section{Výstupy testovania pomocou očnej kamery}

Testovanie pomocou očnej kamery vždy prebieha za účelom získania odpovedí na stanovené otázky. Získané výsledky môžu byt' zobrazené vo viacerých formách:

- Heat map - mapa, ktorá pomocou teplotnej škály znázorňuje miesta s najväčšou a najmenšou mierou pozornosti.

- Focus map - mapa zobrazujúca iba skutočne registrované miesta; predstavuje inverzné zobrazenie oproti heat map.

- Scan Path - zobrazuje poradie a dížku fixácie pohl'adu testera. Tieto parametre sú zachytené prostredníctvom kruhov a čiar. Kruhy sú rôznej vel'kosti v závislosti od času zotrvania na danom mieste webu a čiary zobrazujú posun pohl'adu po webovej stránke.

- Gridedd AOI's (štatistická mapa podla zvoleného parametru) - znázorňuje čas (ms), kedy tester sledoval jednotlivé časti testovaného materiálu.

- KPI's - analýza vopred definovaných kl'účových indikátorov, ktoré sa pri testovaní sledujú. [4]

Okrem uvedených grafických výstupov sú d’alšími čiastkovými výstupmi aj analýza času trvania a správania sa užívatel'a a híbkové rozhovory na zistenie všeobecných zvyklostí užívatel'ov na webovej stránke. [6]

\section{Ciele výskumu}

Prioritným ciel'om uživatel'ského testovania bolo odhalit' nedostatky v logickom usporiadaní webovej stránky kompava.sk a taktiež aj pôsobenie jej grafickej podoby www na návštevníka. Aby bolo možné dosiahnut' prioritný ciel', bolo potrebné splnit' niekol'ko čiastkových ciel'ov:

- určit' dominantné prvky webovej stránky a tiež elementy, ktoré pôsobia rušivo,

- overit' prehl'adnost' a rozloženie stránky,

- overit' správne umiestnenia informácií v prostredí skúmanej webovej stránky,

- zistit' vplyv farieb a grafiky na návštevníkov testovanej stránky.

Taktiež bolo potrebné stanovit' ciele webovej stránky:

- bezproblémové nájdenie hl'adaného produktu,

- registrácia návštevníka,

- spokojnost' zákazníka s priebehom nákupu,

- opakujúci sa nákup v elektronickom obchode kompava.sk,

V nadväznosti na uvedené ciele webovej stránky boli určené konkrétne prvky a procesy, na ktoré sme $\mathrm{v}$ procese testovania upriamili najviac pozornosti:

- proces hl'adania vybraného produktu,

- registrácia zákazníka,

- nákupný proces,

- zistenie podmienok vernostného programu.

\section{Metódy skúmania}

Objektom skúmania bola webová stránka elektronického obchodu kompava.sk, na ktorej bolo realizované užívatel'ské testovanie pomocou očnej kamery. V rámci výskumu bolo použitých niekol'ko metód skúmania: 
- Očná kamera - prostredníctvom ktorej sme sa dozvedeli na ktoré časti webovej stránky a ako dlho sa užívatel' pozeral a aké boli jeho reakcie.

- Híbkový rozhovor - ktorý sa realizoval ihned' po uskutočnení užívatel'ského testovania, aby sme od testerov dozvedeli bezprostredné pocity, postrehnuté chyby, ako aj námety na zlepšenie.

- Metóda analýzy - použitá pri podrobnej analýze údajov získaných od jednotlivých testerov.

- Analýza záznamov z testovania - do formulárov bolo zaznamenávané správanie jednotlivých testerov, ich chybovost' a čas plnenia stanovenej úlohy pri realizácii uživatel'ského testovania skúmanej webovej stránky.

\section{Realizácia a výsledky skúmania}

Pri realizácii užívatel'ského testovania webovej stránky elektronického obchodu kompava.sk sme sa rozhodli zamerat' svoju pozornost' na bežných užívatel'ov internetu, ktorí uskutočňujú nákup cez internet, avšak zatial' nenakupovali cez elektronický obchod kompava.sk. Takýto výber by mal zaručit' dôveryhodnost' a relevantnost' dosiahnutých výsledkov užívatel'ského testovania.

Testovanie prebiehalo podl'a vopred stanoveného scenára, ktorý obsahoval niekol'ko úloh:

1. Vol’ne si pozrite webovú stránku kompava.sk.

2. Predstavte si, že máte problémy s kíbmi. Pozrite si, aké vhodné produkty má firma $\mathrm{v}$ ponuke.

3. Zaujal vás produkt GELO 3-complex. Prečítajte si podrobnejšie, na čo je určený.

4. Rozhodli ste sa pre kúpu produktu Gelo-3 complex. Vložte ho do košíka.

5. Máte $\mathrm{v}$ pláne nakupovat' $\mathrm{v}$ danom elektronickom obchode aj $\mathrm{v}$ budúcnosti. Zaujíma Vás, či sa Vám tu oplatí pravidelne nakupovat'. Zistite podmienky vernostného programu.

6. Vernostný program Vás zaujal. Vyhl’adajte registráciu nového zákazníka.

Užívatel'ské testovanie bolo uskutočnené za účelom zvýšenia použitel'nosti webovej stránky elektronického obchodu kompava.sk. Vd’aka tomu boli odhalené chyby a nedostatky $\mathrm{v}$ logickej a grafickej štruktúre stránky, ktoré spôsobovali užívatel'om problémy alebo na nich pôsobili rušivo. To malo za následok časté opustenie prostredia stránky, nedokončenie objednávky, a teda neuskutočnenie nákupu. Výsledkom užívatel'ského testovania boli návrhy, ako vylepšit' webovú stránku elektronického obchodu a tým predíst' nechceným aktivitám návštevníkov a potenciálnych zákazníkov elektronického obchodu.

\section{Vyhodnotenie jednotlivých úloh}

Úloha č. 1: Vol'ne si pozrite webovú stránku kompava.sk.

Úloha spočívala $\mathrm{v}$ oboznámení sa $\mathrm{s}$ vybranou webovou stránkou po dobu 30 sekúnd. Testeri mali možnost' pozriet' si štruktúru stránky, jednotlivé záložky v hornom a l'avom menu a tiež jej navigáciu. Väčšina testerov sa zdržiavala len v hlavnej časti stránky a neposunula sa za jej zlom. Všímali si hlavne reklamu zobrazenú ako prvú na hlavnej stránke, najoblúbenejší produkt pod touto reklamou a tiež jednotlivé záložky v oboch menu. Heat mapa znázorňujúca prvých 20 sekúnd pozerania je zobrazená na obr. 1 . 


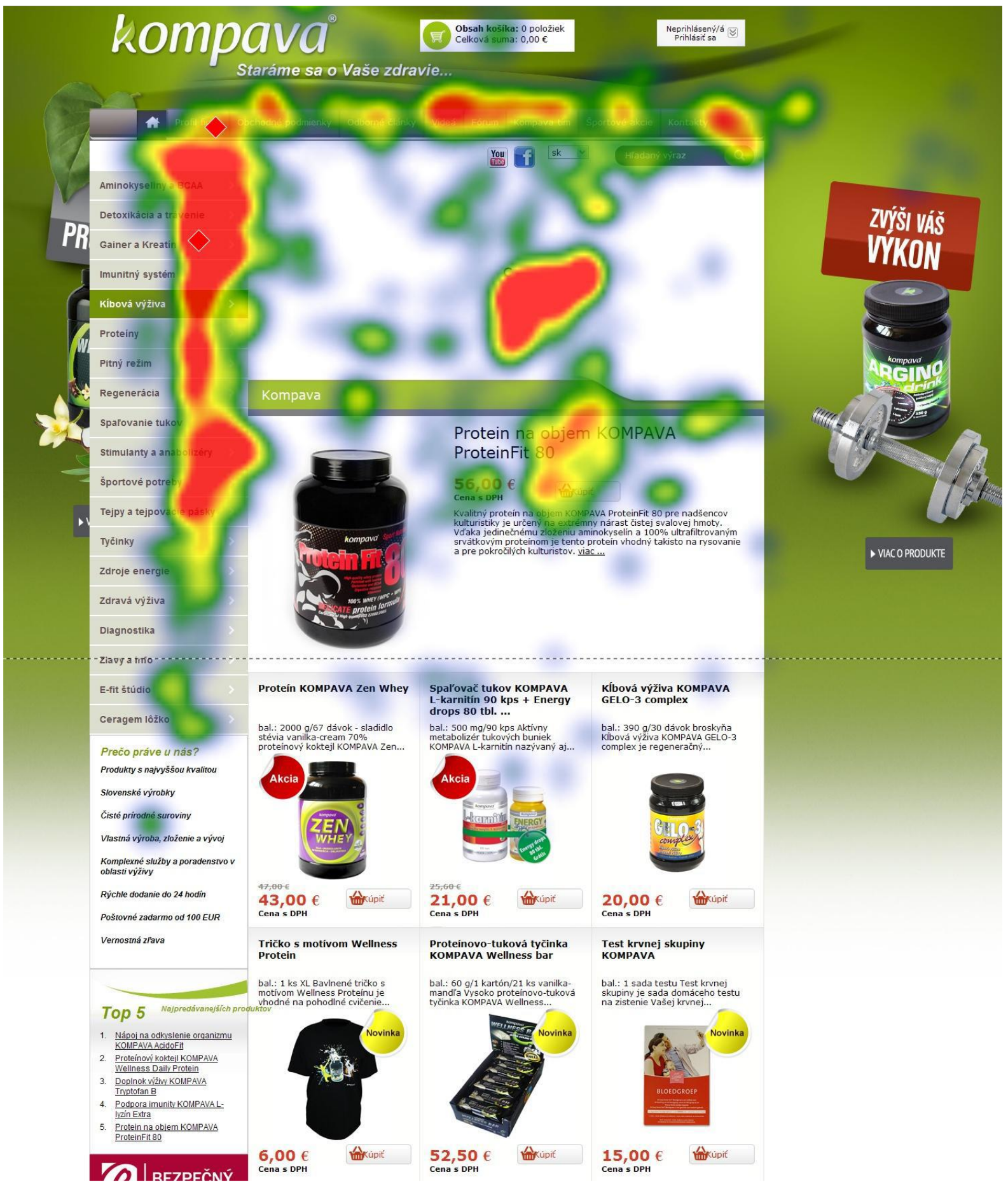

Obrázok 1 Heat mapa znázorňujúca prvých 20 sekúnd prezerania stránky

Úloha 2: Predstavte si, že máte problémy s kĺbmi. Pozrite si, aké vhodné produkty má firma $\mathrm{v}$ ponuke.

Daná úloha patrila $\mathrm{k}$ tým l'ahším úlohám počas testovania a bola splnená bez problémov všetkými testermi. Každý z nich použil l'avé menu, kde klikol na záložku „Kíbová výživa“ a ani jeden nezadal požiadavku do vyhl'adávania na webovej stránke. Pohl'ady jednotlivých testerov pri hl'adaní ponuky produktov na kíby boli zachytené pomocou Scan Path (obr. 2). 


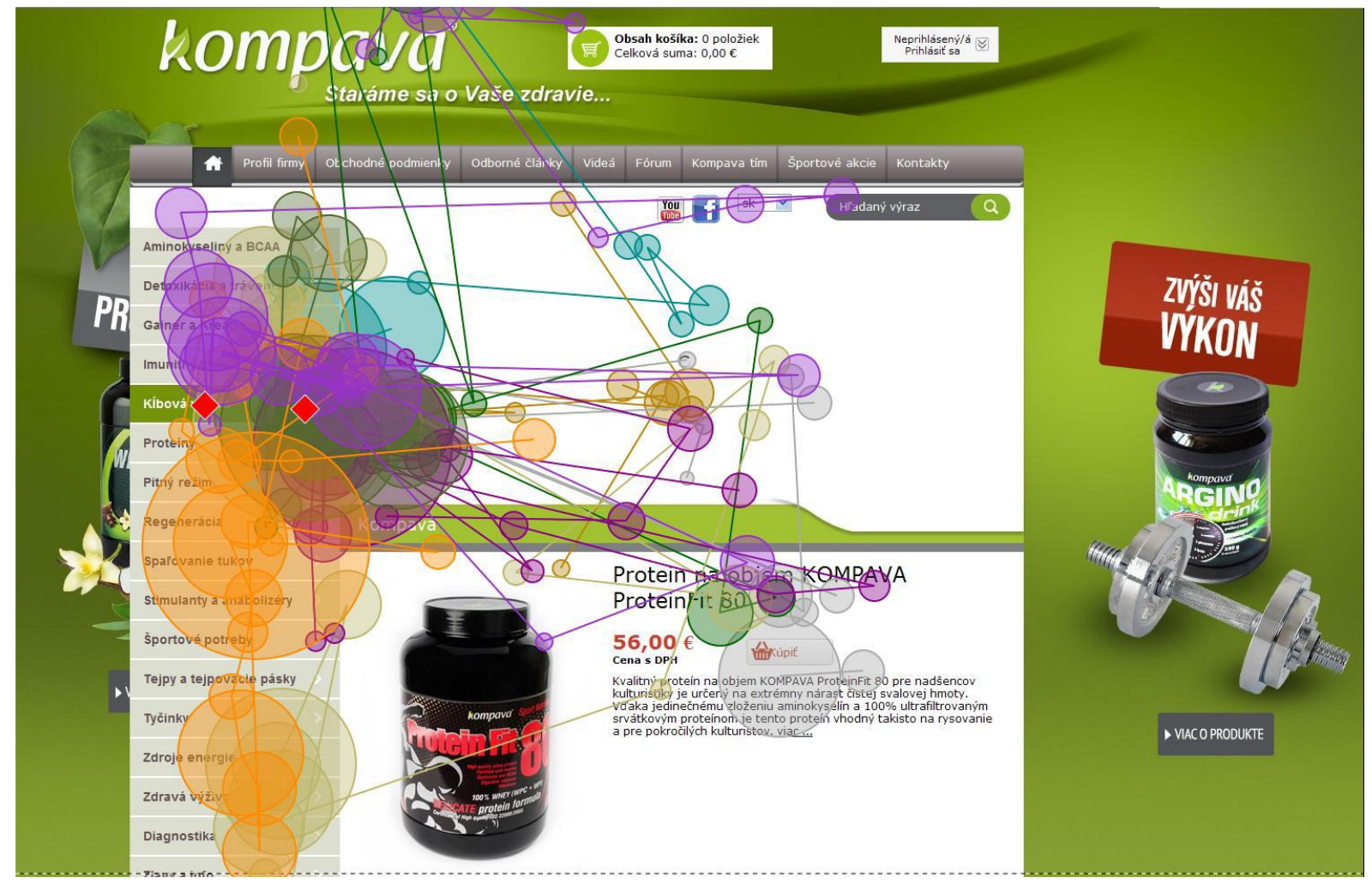

Obrázok 2 Scan Path - hl'adanie ponuky produktov na kíby

Úloha 3: Zaujal vás produkt GELO 3-complex. Prečítajte si podrobnejšie, na čo je určený.

Úlohu splnili všetci testeri. Väčšina konkrétny produkt našla filtrovaním produktov $\mathrm{v}$ záložke „Kíbová výživa“. Dvaja testeri zadali názov produktu do vyhl’adávania webovej stránky a tak našli žiadaný produkt. Po kliknutí na produkt si všetci testeri zbežne prečítali hlavný, ale aj podrobnejší popis daného produktu, ktorý sa zobrazil priamo pri produkte. Nasledujúci obrázok zaznamenáva pohl'ady testerov na stránke vybraného produktu pomocou Heat map (obr. 3).

Úloha 4: Nakoniec ste sa rozhodli pre kúpu produktu Gelo-3 complex. Vložte ho do košíka.

Daná úloha bola vel'mi jednoduchá a ked’že predpokladáme, že každý z testerov už nakupoval $\mathrm{v}$ nejakom elektronickom obchode, tak presne vedel ako postupovat'. Úlohu podl'a očakávania splnili všetci testeri vel'mi rýchlo a bez najmenších problémov. Každý jeden tester klikol na piktogram košík vyobrazený pri vybranom produkte.

Úloha 5: Máte v pláne nakupovat' $\mathrm{v}$ danom elektronickom obchode aj v budúcnosti. Zaujíma Vás, či sa Vám tu oplatí pravidelne nakupovat'. Zistite podmienky vernostného programu.

Prekvapivo až pät' testerov hl'adalo vernostný program $\mathrm{v}$ hornom menu, $\mathrm{v}$ záložke „Obchodné podmienky“ a museli sa prácne dostat' až na úplný koniec stránky, kde boli podmienky vernostného programu uvedené. Iba jeden tester podla očakávaní použil l'avé menu a záložku „Kompava KLUB“. Vel'mi mätúci bol neklikatel'ný odkaz „Vernostná zl’ava“, ktorý bol súčast’ou zoznamu „Prečo práve u nás?“, umiestneným pod l’avým menu. Testeri sa snažili na odkaz kliknút' a ked' zistili, že nefunguje neboli ochotní vernostný program d'alej hl'adat'. Hl'adanie podmienok vernostného programu zobrazuje Heat mapa (obr. 4). 


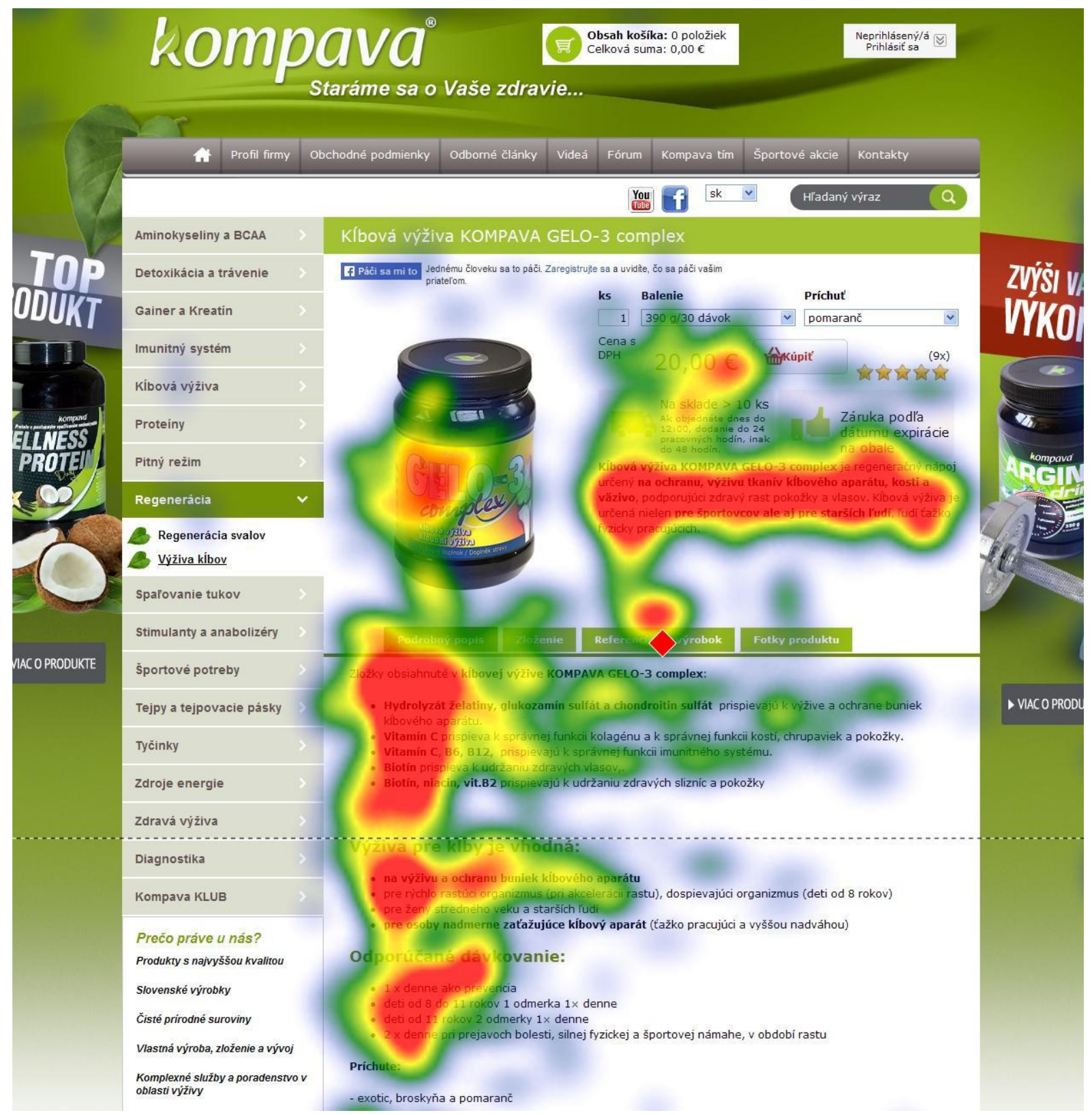

Obrázok 3 Heat mapa - popis vybraného produktu

Úloha 6: Vernostný program Vás zaujal. Vyhlaadajte registráciu nového zákazníka.

Všetci testeri splnili úlohu rýchlo a intuitívne, pričom použili odkaz „Prihlásit’ sa“ vpravo hore na stránke. Jeden tester sa chcel registrovat' priamo v prostredí vernostného programu, čo sa mu nepodarilo a tak nakoniec použil spomínaný odkaz. 


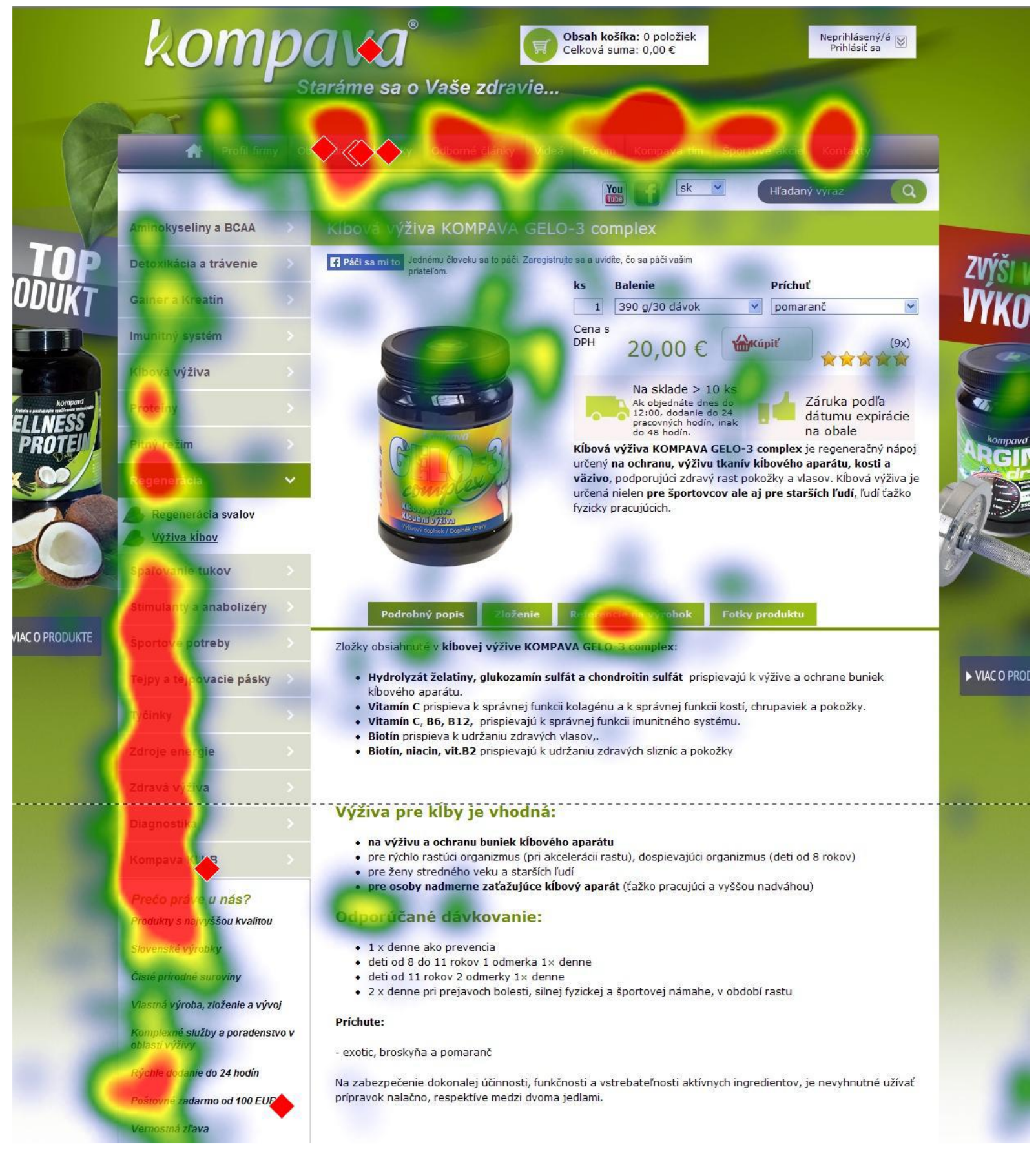

\section{Obrázok 4 Heat mapa - hl’adanie podmienok vernostného programu}

Po ukončení testovania pomocou očnej kamery boli testeri podrobení híbkovému rozhovoru, kde im moderátor kládol otázky a oni na základe pocitov a dojmov z užívatel'ského testovania odpovedali na tieto otázky:

- Aký dojem vo Vás webová stránka vyvolala?

- Čo Vám na webovej stránke spôsobovalo najväčšie problémy?

- Akú zmenu by ste na webovej stránke privítali?

Odpovede na uvedené otázky pomohli odhalit' chyby na stránke kompava.sk a tiež boli nápomocné pri vytváraní návrhov na jej zlepšenie. 
Vyhodnotením užívatel'ského testovania a híbkového rozhovoru sme zistili konkrétne nedostatky, ktoré môžeme rozdelit' do dvoch skupín:

- kritické nedostatky - spôsobujú to, že užívatel' nevie určitú úlohu dokončit' - napr. neúplné vyhl'adávanie informácií na stránke, chýbajúca navigácia;

- problémové miesta - uživatel' je schopný splnit' zadanú úlohu, ale iným spôsobom, ako by očakával - napr. neklikatel'ný piktogram nákupného košíka na prezretie objednávky, neklikatel’ný odkaz na vernostný program, nesystematické usporiadanie horného menu a pod.

\section{Návrhy a odporúčania}

Na základe získaných informácií sme navrhli možné zlepšenia, ktoré by mali byt' užitočné zlepšenie stránky elektronického obchodu kompava.sk.

- Zlepšenie vyhl'adávania na webovej stránke - vyhl'adávanie bolo schopné nájst' iba produkty a súvisiace odborné články, ostatné informácie súvisiace $\mathrm{s}$ nákupným procesom neboli nájdené. Pre by bolo vhodné doplnit' tieto informácie do vyhl'adávania a tiež indexovat' názvy produktov aj s ich možnými preklepmi.

- Vytvorenie odkazu na podmienky vernostného programu - pretože práve tie patrili medzi prvky, ktorých hl'adanie spôsobovalo užívatel'om počas testovania značné problémy. Riešením je vytvorenie odkazu ohl'adom vernostného programu na viditel'né miesto webovej stránky, aby ich užívatel' spozoroval ihned' po otvorení stránky. Odkazy by boli klikatel'né, situované nad l'avým menu, kde by boli súčast'ou zoznamu „Prečo práve u nás?“.

- Doplnenie navigácie - $\mathrm{v}$ hornej časti webovej stránky sa nenachádzajú odkazy na sekciu prípadne podsekciu, v ktorej sa užívatel' aktuálne nachádza. Je potrebné doplnit' navigáciu, aby sa užívatel' l'ahšie vrátil z produktovej stránky na vybranú sekciu a tiež aby mal jednoznačný prehl'ad o tom, $\mathrm{v}$ ktorej sekcii alebo podsekcii sa nachádza.

- Zmena štruktúry horného menu - niektoré záložky horného menu stránky boli neúčelové a rôznorodé. Patrili k nim najmä „Odborné články“, „Videá“ a „Športové akcie“, ktoré nie sú tak dôležité pre užívatel'a a predstavujú doplnkové informácie. Z tohto dôvodu by sme ich umiestnili do menej dôležitej časti stránky a ich miesto by sme nahradili atraktívnejšími záložkami. Taktiež bolo potrebné prehodnotit' poradie záložiek v hornom menu, aby mali logickú nadväznost'.

- Zlepšenie vstupu do nákupného košíka - užívatel'ské testovanie odhalilo, že mnoho užívatel'ov pri vstupe do nákupného košíka chcelo použit' neklikatel'ný piktogram košíka v hornej časti stránky. Avšak do košíka bolo možné sa dostat' cez odkaz „Upravit"“ umiestnený pri danom piktograme. Navrhujeme preto sfunkčnit’ piktogram košíka a tak ul'ahčit' užívatel'om proces nákupu.

\section{Záver}

Elektronický obchod kompava.sk disponoval prít’ažlivou webovou stránkou, ktorá bola na prvý pohl'ad fungujúca a bezchybná. Ovládanie jej prvkov bolo intuitívne a tiež bola l'ahko zapamätatel'ná. Realizáciou užívatel'ského testovania boli však odhalené viaceré zásadné, ale aj menšie chyby a nedostatky, ktoré bránili užívatel'om dokončit žiadané úlohy. $Z$ tohto dôvodu sme na základe vyhodnotenia užívatel'ského testovania a hĺbkového rozhovoru s testermi navrhli niekol'ko rád a odporúčaní pre zlepšenie stránky. Niektoré z návrhov sú nevyhnutné pre zabránenie straty potenciálnych zákazníkov a d'alšie sú zas akousi radou, ako by mohla byt' stránka viac atraktívna a l’ahšie použitel'ná.

\section{Literatúra}

[1] DUCHOWSKI, A.T. Eye Tracking Methodology : Theory and Practice. 2. vyd. London : Springer Verlag, 2007. 360 s. ISBN 978-1-846928-608-7. 
[2] HAMMOUD, R.I. Passive Eye Monitoring : Algorithms, Applications and Experiments. Berlin : Springer Verlag, 2008. 497 s. ISBN 978-3-540-75411-4.

[3] JANOUCH, V. Internetový marketing : Prosad'te se na webu a sociálních sitich. Brno : Computer Press, a. s., 2010. 304 s. ISBN 978-80-251-2795-7.

[4] ŠPANIHEL, J. Uživatelské testováni jinak. Nově a lépe. 2009 [online]. Symbio, 2009. [cit. 2013-11-17]. Dostupné na internete: <http://www.symbio.cz/clanky/uzivatelske-testovanijinak-nove-a-lepe.html>.

[5] Očnou kamerou možno zistit’, čo skutočne vnímame [online]. [s.a.]. [cit. 2013-11-17]. Dostupné na internete: <http://technologie.etrend.sk/technologie/ocnou-kamerou-moznozistit-co-skutocne-vnimame.html>.

[6] Priebeh testovania statickou kamerou [online]. [s.a.]. [cit. 2014-1-18]. Dostupné na internete:<http://www.constat.sk/constat-digital/priebeh-testovania-statickou-kamerou>.

[7] Testování webu na uživatelích [online]. [s.a.]. [cit. 2013-11-17]. Dostupné na internete: <http://www.optimics.cz/sluzby/optimalizace-webu/testovani-webu-na-uzivatelich>.

[8] Uživatelské testování [online]. [s.a.]. [cit. 2013-11-18]. Dostupné na internete: $<$ http://www.symbio.cz/uzivatelske-testovani.html>.

[9] Uživatelské testování použitelnosti [online]. [s.a.]. [cit. 2013-11-18]. Dostupné na internete: $<\mathrm{http} / / / \mathrm{www} \cdot d o b r y w e b . c z /$ uzivatelske-testovani >.

[10] Užívatel'ské testovanie www stránok [online]. [s.a.]. [cit. 2013-11-17]. Dostupné na internete: <http://www.netperfect.sk/uzivatelske-testovanie-www>.

\section{Grantová podpora}

KEGA 1/0420/14 Moderné prístupy k identifikácii faktorov ovplyvňujúcich nákupné rozhodovanie - výskumné aktivity v oblasti neuromarketingu s využitím očnej kamery 